\title{
Characterization of 5.5 GHz High Gain Microstrip 2x2 Array Antenna
}

\author{
Irfan Mujahidin a,1,* \\ ${ }^{a}$ Telecommunication Labortory, Faculty of Engineering, University of Merdeka Malang, Malang, Indonesia \\ ${ }^{1}$ irfan.mujahidin@unmer.ac.id*
}

\begin{tabular}{|c|c|}
\hline & ABSTRACT \\
\hline $\begin{array}{l}\text { Keywords } \\
\text { High Gain } \\
\text { Array Antenna } \\
\text { Microstrip } \\
5.5 \mathrm{GHz} \text { C Band }\end{array}$ & $\begin{array}{l}\text { This paper presents the plan of the microstrip cluster radio wire on the } 5.5 \mathrm{GHz} \mathrm{C} \text { Band } \\
\text { application. The proposed radio wire comprises } 4 \text { rectangular patches with a microstrip } \\
\text { line nourishing arrange set up employing a transformer impedance quarter wavelength } \\
\text { coordinating strategy. On dodge grinding flaps influenced by the between patches } \\
\text { dispersing, the fixed division to the adjoining radiation element is the collection to be } \\
\text { wavelength with the value is } 0.5 \text {. Thus, to realize tall pick up required by the } 5.5 \mathrm{GHz} \mathrm{C} \\
\text { Band details, the cluster comprised of } 4 \text { radiation element is connected where the } \\
\text { radiation element is organized in } 2 \times 2 \text { (pile x lines) arrangement. The receiving wire } \\
\text { configuration is at that point conveyed on a phonetic white paper substrate in what the } \\
\text { misfortune, digression thickness, and dielectric steady are } 0.0016 \mathrm{~cm}, 4.2 \text {, and } 0.0001 \text {, } \\
\text { separately. The Identification result of return loss, radiation design, pick up, and } \\
\text { impedance coordinating are displayed continuously. From the result, it appears that the } \\
\text { proposed receiving wire has a generally pick up of } 8.95 \mathrm{~dB} \text { and the return mismatch of } \\
32.98 \mathrm{~dB} \text {. }\end{array}$ \\
\hline
\end{tabular}

\section{Introduction}

As of late, the advancement of communication innovation is profoundly expanded and showing proceeds to develop, not slightest with a remote communication framework. Not as it was making progressed innovation increments, the remote communication frameworks such as WiFi (Remote Devotion) and C band route radio as well as their administration's applications are exceptionally well known in existence with a variety of points of interest on the transport, such as to supply communication administrations at anytime and anyplace for the user's area[1][2]. Those events right now can be visible by the expanding request for remote web get to, video chat, cable remote tv, and so on[3].

$\mathrm{C}$ band radio wire innovation that as of late is utilized in numerous nations was set up in a few distinctive recurrence groups for each nation. In Indonesia, it was set up in 2 primary recurrence groups, remote sensors, and remote communication, based on the choice of the reference[4][5]. To back exchange information, voice, and interactive media with high-speed get to the client for such remote transfer data frameworks, it involves communication gadgets that could fulfill foreordained determinations[6][7]. Moreover, in tall speed, remote communication frameworks, the radio wires which can bolster numerous capacities and highlights are one of the challenging points that require more consideration. Even though the microstrip-patch radio wire has a few points of interest, it moreover has a few drawbacks such as moo pick up, contract transfer speed with moo effectiveness[8][9]. These impediments can be overcome by developing numerous fix receiving wires within the $\mathrm{n}$ cluster setup. Other endeavors have to been explored, some of them are employing a printed dipole radio wire that legitimately designed.

In this research, the identification of a tall pickup line strip cluster radio wire with a circuit line nourishing organize is displayed[10][11]. The recommendation radio wire is outlined 5 to have the center recurrence of $5.5 \mathrm{GHz}$ which is reasonable for $\mathrm{C}$ band remote communication application. It 
comprises of 4 rectangular patches receiving wire organized in $2 \times 2$ (columns $\mathrm{x}$ lines) arrangement to get a tall pick up compulsory by the necessity[12][13]. The isolation between the radiation element is additionally analyzed to play down grinding projections as the huge dividing. The plan of the $2 \times 2$ microstrip cluster radio wire is at that point conveyed on a double-sided phenolic white paper substrate[14][15]. At long last, the characterization of the receiving wire is the formula implement where the comes about just like the loss of signal od $\mathrm{dB}$, pattern design, pick up, and impedance coordinating are oppose with the plan detail.

\section{Antenna Design}

In planning a line strip receiving wire, the various dielectric element can be utilized to attain a great reaction and their relative permittivity are more often than not within the run of $2.2 \leq \mathrm{fr} \leq 12$. In a perfect world, the permittivity relative of the value of dielectric element bought to be of (fr $<4.3$ ), to augment the bordering areas that tick for the emission[16][17]. The foremost alluring dielectric element for great radio wire execution is generally a thick dielectric element whereby the permittivity relative is at the reduced conclusion. Typically since this extends gives es superior execution compared to the lean substrate[18]. To get ideal plan characteristics, the engineering of the receiving wire is examined numerically. Execution assessment on the cluster of the receiving wire is subsequently established once the only fix radio wire has been built up the characteristic of the element substrate[19][20].

Table 1. Parameters Of Dielectric Substrate For Deployment

\begin{tabular}{ll}
\hline \multicolumn{1}{c}{ Parameter } & \multicolumn{1}{c}{ Dimension } \\
\hline Center frequency & $5.5 \mathrm{GHz}$ \\
\hline Dielecrtric substrate & Phonelic White Paper \\
\hline Dielectric constant & 4.3 \\
\hline Thickness of Substrate & $0.0016 \mathrm{~cm}$ \\
\hline loss tangent on Substrate & 0.0001 \\
\hline thickness of Copper & $0.035 \mathrm{~mm}$ \\
\hline
\end{tabular}

\subsection{Single Microstrip Antenna Design}

The execution of the patch radio wire hinges on its measurement which too impacts the working recurrence, emission effectiveness, gain, return mismatch, and other bound up characteristics. The plan of the circiut strip radio wire is started by deciding its fixed measurement. The width (W) and the length (L) of the fix.

$$
\begin{aligned}
& W p=\frac{v_{0}}{2 f_{r}} \sqrt{\frac{2}{\epsilon_{r}+1}} \\
& L p=\frac{1}{2 f_{r} \sqrt{\epsilon_{\text {reff }}} \sqrt{\mu_{0} \epsilon_{0}}}-2 \Delta L
\end{aligned}
$$

Where Wp is the settled width, Lp is the settled length, v0 is the light free-space speed, er is the dielectric of the relative permittivity of the substrate, and fr is the booming recurrence[21][22]. From (1)-(2) to get the thunderous recurrence of $5.5 \mathrm{GHz}$, the length (L) and the width (W of the fix are $12.5 \mathrm{~mm}$ and $16.6 \mathrm{~mm}$, individually, as outlined in Fig. 1. As the ordinary pharameter of the line strip circuit receiving wire has moo pick up, hence it is overcome by building the radio wire in a cluster configuration[23][24].

\subsection{The Design of Microstrip Array Antenna}

As appeared in Fig. 2, since the receiving wire cluster is outlined utilizing a 4 boxes radiation element organized in $2 \times 2$ (pile $\mathrm{x}$ row) arrangement, in this way the corporate nourishing arrange is selected to nourish all radiation elements. The cluster of radio wire comprises of a few ramification systems of 1-line control dividers[25][26]. following a few characteristics ponder, the division between radiation element is set to be 0.5 of wavelength to dodge grinding projections. A quarter part 
of length-wave. Figure 2 appears the plan of a $2 \times 2$ microstrip cluster receiving wire with the corporate nourishing organize[27][28]. While the measurement of every strip circuit receiving wire is purposeful utilizing (1) and (2) in that the measurement is comparative to the only line strip receiving wire.

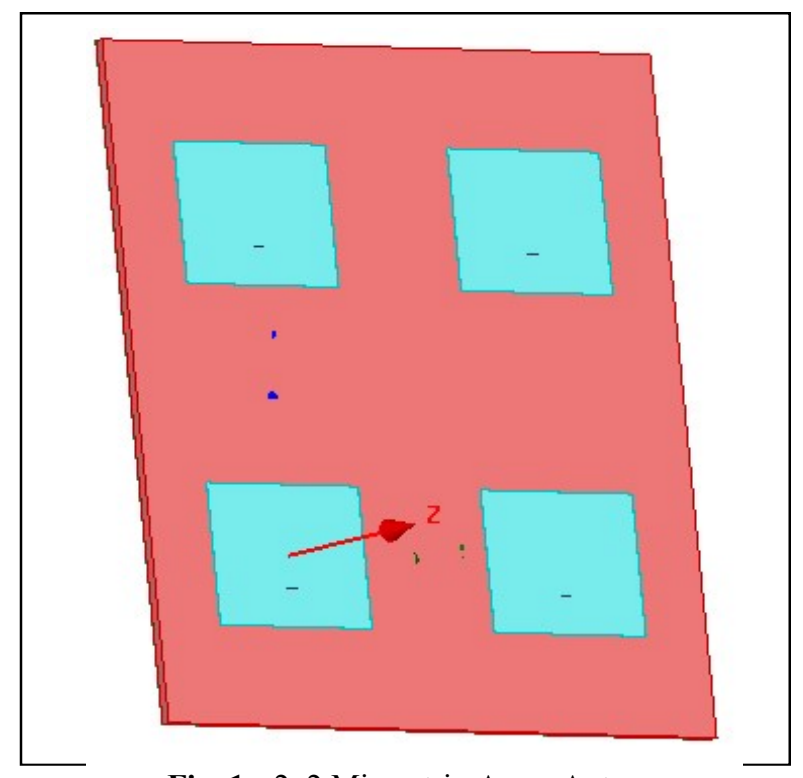

Fig. 1. $2 \times 2$ Microstrip Array Antenna

\section{Analysis and Characterization}

From the plan result, the recommendation mono line strip receiving wire and $2 \times 2$ microstrip cluster receiving wire are at that point conveyed on a double-sided phenolic white paper dielectric element with $<\mathrm{r}$ of 4.2 , the consistency of $0.0016 \mathrm{~cm}$, and mismatch digression of 0.0001 [29]. To get the parameter execution, both recommendation radio wires are at that point parameter theoretically. The parameters incorporate the examination of a few characteristic such as loss return, emission design, and power gain[30]. The parameters result of return mismatch for a monoline strip radio wire and $2 \times 2$ line strip antenna cluster receiving wire within the recurrence extend of $5-6 \mathrm{GHz}$ is portrayed in Figure. 2. From the charts, it ought to be famous that the resounding recurrence of a single microstrip receiving wire is $5.5 \mathrm{GHz}$ with the esteem of return misfortune is $32.98 \mathrm{~dB}$ [31]. Even though the resounding recurrence of the $2 \times 2$ microstrip cluster receiving wire is somewhat moved higher.

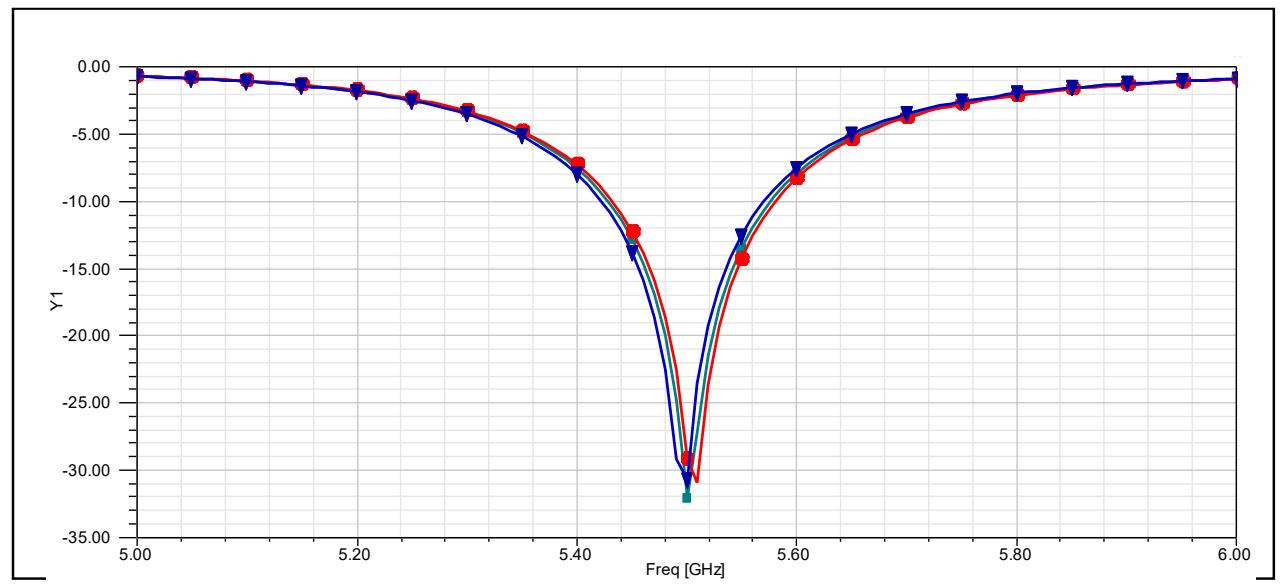

Fig. 2. Return loss of $2 \times 2$ Microstrip Array Antenna 
Figures 2 delineate the characterized comes about of a radiation design for a single microstrip radio wire and a $2 \times 2$ microstrip cluster receiving wire. It appears that the radiation design of the $2 \times 2$ microstrip cluster receiving wire has a few minor projections and isn't $\mathrm{s}$ smooth as the single microstrip receiving wire[32]. Typically for the most part lead by the number of radiation elements arranged in an array configuration that influences the extra flap next than the most flap. Even though the hand projections can be miniaturized by designing the bolstering arrange and radiation element separation, be that as it may, as the beck lobes are compacted the pick-up is diminished[33][34]. Hence, there's a sell-off that must be settled more consideration among the radio wire pick up and its side flaps.

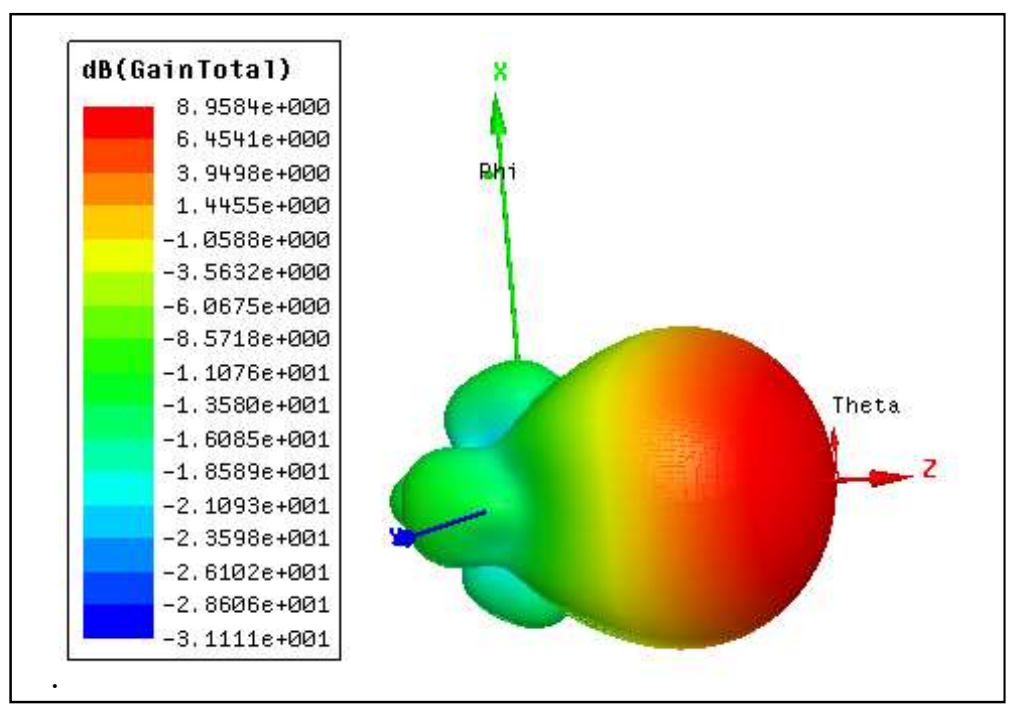

Fig. 3. Radiation Pattern of $2 \times 2$ array antenna

The characterized comes about of pick up for single microstrip receiving wire and $2 \times 2$ microstrip cluster radio wire within the recurrence extend of $5-6 \mathrm{GHz}$ are plotted in Figure. 5. The comes about to appear that the top pick up of the $2 \times 2$ microstrip cluster receiving wire appeared in Fig. 6 is $8.95 \mathrm{~dB}$ at $5.5 \mathrm{GHz}$ indicated this is often $3 \mathrm{~dB}$ more elevated than the gain of mono patch antenna radio wire. This result has demonstrated that the cluster structure is viably appropriate to extend the pick up of the radio wire.

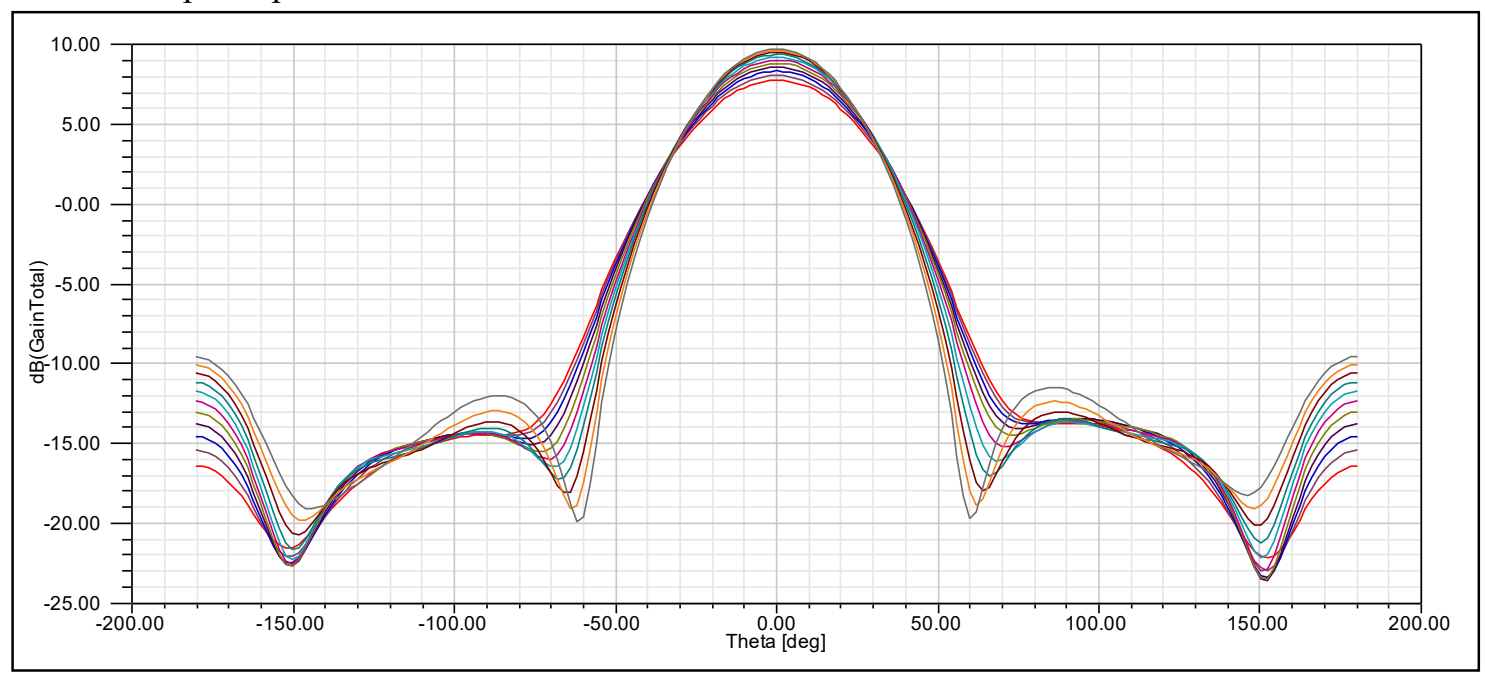

Fig. 4. Power gain value of $2 \times 2$ array antenna 
To decide, the electromagnetic structure is sweet work we must distinguish the impedance yield. the impedance yield can be appeared with a Smith chart realistic. Figure 7 has appeared the impedance yield of the $5.5 \mathrm{GHz}$ Microstrip 2x2 Cluster Radio wire.

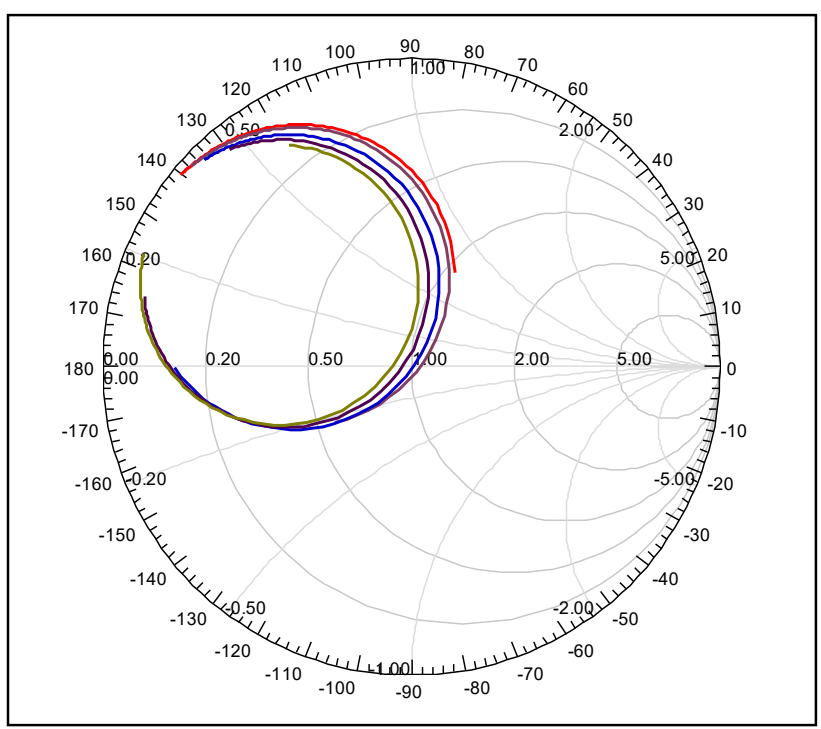

Fig. 5. The characteristic impedance of the $5.5 \mathrm{GHz}$ Microstrip $2 \times 2$ Array Antenna.

The value of characteristic impedance the port of $0.98+0.12 \mathrm{i}$, it can be normalized level resistance of the overall value is near $50 \mathrm{ohms}$. its requirement good implemented.

\section{Conclusion}

The plan and characterization of the microstrip cluster radio wire on the $5.5 \mathrm{GHz} \mathrm{C}$ Band application. The proposed radio wire comprises 4 rectangular patches with a microstrip line nourishing organize set up employing a transformer impedance quarter wavelength coordinating strategy. On dodge grinding flaps influenced by the between patches dispersing, the fixed division to the adjoining radiation element is the collection to be wavelength with the value is 0.5 . Thus, to realize tall pick up required by the $5.5 \mathrm{GHz} \mathrm{C}$ Band details, the cluster comprised of 4 radiation element is connected where the radiation element is organized in $2 \times 2$ (pile $\mathrm{x}$ lines) arrangement. The receiving wire configuration is at that point conveyed on a phonetic white paper substrate in what the misfortune, digression thickness, and dielectric steady are $0.0016 \mathrm{~cm}, 4.2$, and 0.0001 , separately. The Identification result of return loss, radiation design, pick up, and impedance coordinating are displayed continuously. From the result, it appears that the proposed receiving wire has a generally pick up of $8.95 \mathrm{~dB}$ and the return mismatch of $32.98 \mathrm{~dB}$ that compares to a recurrence of $5.51 \mathrm{GHz}$, while the working transfer speed is $100 \mathrm{MHz}$ ranges from $5.46-5.55 \mathrm{GHz}$. the impedance characteristic is $50 \mathrm{Ohm}$. 
[1] R. Yuwono, I. Mujahidin, A. Mustofa, and Aisah, "Rectifier using UFO microstrip antenna as electromagnetic energy harvester," Adv. Sci. Lett., 2015, doi: 10.1166/asl.2015.6574.

[2] I. Mujahidin, "DIRECTIONAL 1900 MHZ SQUARE PATCH RING SLOT MICROSTRIP ANTENNA FOR WCDMA," JEEMECS (Journal Electr. Eng. Mechatron. Comput. Sci., 2019, doi: 10.26905/jeemecs.v1i2.2626.

[3] I. Mujahidin, R. Yuwono, and A. Mustofa, "RANCANG BANGUN RECTIFIER ANTENNA MIKROSTRIP UFO PADA FREKUENSI ULTRA WIDEBAND (UWB) SEBAGAI PEMANEN ENERGI ELEKTROMAGNETIK," J. Mhs. TEUB, vol. 3, no. 2, 2015.

[4] M. T. Prakarsa, D. Wahyuni, N. Rachman, and I. Mujahidin, "OPTIMASI SISTEM KOMUNIKASI DARI HT DENGAN HP DALAM PELAKSANAAN TUGAS OPERASI TNI AD MENGGUNAKAN METODE DTMF," JASIEK (Jurnal Apl. Sains, Informasi, Elektron. dan Komputer), 2019, doi: 10.26905/jasiek.v1i1.3150.

[5] J. Lasmono, A. P. Sari, E. Kuncoro, and I. Mujahidin, "OPTIMASI KERJA PELUNCUR ROKET PADA ROBOT RODA RANTAI UNTUK MENENTUKAN KETEPATAN SUDUT TEMBAK," JASIEK (Jurnal Apl. Sains, Informasi, Elektron. dan Komputer), 2019, doi: 10.26905/jasiek.v1i1.3149.

[6] I. Mujahidin, S. H. Pramono, and A. Muslim, "5.5 Ghz Directional Antenna with 90 Degree Phase Difference Output," 2018, doi: 10.1109/eeccis.2018.8692872.

[7] I. Mujahidin and B. F. Hidayatulail, "2.4 GHz SQUARE RING PATCH WITH RING SLOT ANTENNA FOR SELF INJECTION LOCKED RADAR," JEEMECS (Journal Electr. Eng. Mechatron. Comput. Sci., vol. 2, no. 2, 2019.

[8] M. Wibowo, S. Suprayogi, and I. Mujahidin, "RANCANG BANGUN SISTEM PENGAMANAN RAK SENJATA M16 MENGGUNAKAN RFID DAN FINGERPRINT," JASIEK (Jurnal Apl. Sains, Informasi, Elektron. dan Komputer), vol. 1, no. 2, pp. 134-142, 2019.

[9] I. Mujahidin, "Langkah Desain Antena," http://antenapropagasi.blogspot.com/2016/02/langkah-desain-antena.html. 2018.

[10] E. Endrayana, D. H. S. Wahyuni, N. Nachrowie, and I. Mujahidin, "VARIASI GROUND PLANE ANTENA COLLINEAR PADA PEMANCAR TELIVISI ANALOG DENGAN FREKUENSI UHF 442 MHz," JASIEK (Jurnal Apl. Sains, Informasi, Elektron. dan Komputer), vol. 1, no. 2, pp. 149-156, 2019.

[11] I. Mujahidin, "VSWR (Voltage Standing Wave Ratio) dan Return loss," http://antenapropagasi.blogspot.com/2016/02/vswr-voltage-standing-wave-ratio-dan.html. 2018.

[12] D. F. C. Kusuma, D. A. Prasetya, F. Kholid, and I. Mujahidin, "EVALUASI DATABASE SENJATA UNTUK SISTEM KEAMANAN MENGGUNAKAN FUZZY LOGIC," JASIEK (Jurnal Apl. Sains, Informasi, Elektron. dan Komputer), vol. 1, no. 2, pp. 111-116, 2019.

[13] I. Mujahidin, "PLL (Phase Locked Loop)," http://antenapropagasi.blogspot.com/2018/11/pll-phase-locked-loop.html. 2018.

[14] A. E. Pambudi, L. Maajid, J. Rohman, and I. Mujahidin, "APLIKASI PENGGUNAAN JOYSTICK SEBAGAI PENGENDALIAN REMOTE CONTROL WEAPON STATION (RCWS) SENJATA MESIN RINGAN (SMR)," JASIEK (Jurnal Apl. Sains, Informasi, Elektron. dan Komputer), vol. 1, no. 2, pp. 98-105, 2019.

[15] I. Mujahidin, "Smart Transducers," http://antenapropagasi.blogspot.com/2018/11/smarttransducers.html. 2018.

[16] S. K. Sugiarto, I. Mujahidin, and A. B. Setiawan, "2, 5 GHz Antena Mikrostrip Polarisasi Circular Model Patch Yin Yang untuk Wireless Sensor," JEECAE (Journal Electr.

Electron. Control. Automot. Eng., vol. 4, no. 2, pp. 297-300, 2019.

[17] I. Mujahidin, "Directional Couplers,"

140| P a g e 
http://antenapropagasi.blogspot.com/2018/11/directional-couplers.html, no. 1. 2018.

[18] B. F. Hidayatulail and I. Mujahidin, "POTENTIAL OF 77, $78 \mathrm{~mW}$ RED DIODE LASER FOR PHOTODYNAMIC," JEEMECS (Journal Electr. Eng. Mechatron. Comput. Sci., vol. 2, no. 2, 2019.

[19] I. Mujahidin and P. S. Arinda, "Antena Compact Double Square Marge 2, 6GHz Dengan Output Perbedaan Fase 90 Derajat Untuk Aplikasi LTE," JEECAE (Journal Electr. Electron. Control. Automot. Eng., vol. 4, no. 2, pp. 273-278, 2019.

[20] I. Mujahidin, "Radar Introduction Class," http://antenapropagasi.blogspot.com/2018/11/radar-introduction-class.html, no. 2. 2018.

[21] R. Yuwono and I. Mujahidin, "Rectifier using UWB microstrip antenna as electromagnetic energy harvester for GSM, CCTV and Wi-Fi transmitter," J. Commun., 2019, doi: 10.12720/jcm.14.11.1098-1103.

[22] I. Mujahidin, "Tutorial Memulai CST- project baru Untuk antena mikrostrip," http://antenapropagasi.blogspot.com/2016/02/tutorial-memulai-cst-project-baruuntuk.html. 2018.

[23] D. A. Prasetya, A. Sanusi, G. Chandrarin, E. Roikhah, I. Mujahidin, and R. Arifuddin, "Small and Medium Enterprises Problem and Potential Solutions for Waste Management," J. Southwest Jiaotong Univ., vol. 54, no. 6, 2019.

[24] I. Mujahidin, "Desain Matematis Antena Mikrostrip," http://antenapropagasi.blogspot.com/2016/02/desain-matematis-antenamikrostrip_17.html. 2018.

[25] I. Mujahidin, D. A. Prasetya, A. B. Setywan, and P. S. Arinda, "Circular Polarization 5.5 GHz Double Square Margin Antenna in the Metal Framed Smartphone for SIL Wireless Sensor," in 2019 International Seminar on Intelligent Technology and Its Applications (ISITIA), 2019, pp. 1-6.

[26] I. Mujahidin, "Parameter Antena," http://antenapropagasi.blogspot.com/2016/02/parameter-antena.html. 2018.

[27] D. A. Ayubi, D. A. Prasetya, and I. Mujahidin, "Pendeteksi Wajah Secara Real Time pada 2 Degree of Freedom (DOF) Kepala Robot Menggunakan Deep Integral Image Cascade," Cyclotr. J. Tek. ELEKTRO, vol. 3, no. 1, 2020.

[28] I. Mujahidin, "Elemen Antena," http://antenapropagasi.blogspot.com/2016/02/elemenentena.html. 2018.

[29] T. A. S, A. Rabi', D. Minggu, and I. Mujahidin, "FREQUENCY HOPPING VIDEO REAL TIME UNTUK PENGAMANAN DATA PENGINTAIAN OPERASI INTELIGENCE TNI," JASIEK (Jurnal Apl. Sains, Informasi, Elektron. dan Komputer), 2019, doi: 10.26905/jasiek.v1i1.3146.

[30] D. A. Prasetya, A. Sanusi, G. Chandrarin, E. Roikhah, I. Mujahidin, and R. Arifuddin, "Community Culture Improvisation Regarding Waste Management Systems and Per Capita Income Increase,” J. Southwest Jiaotong Univ., vol. 54, no. 6, 2019.

[31] I. V. RobbyValentino, N. Nachrowie, D. W, and Mujahidin, "Rancang Bangun Sistem Penilaian Kesegaran Jasmani A Di Jajaran TNI-AD Berbasis RFID," JASIEK (Jurnal Apl. Sains, Informasi, Elektron. dan Komputer), vol. 2, no. 1, pp. 98-106, 2020.

[32] I. Mujahidin, D. A. Prasetya, Nachrowie, S. A. Sena, and P. S. Arinda, "Performance tuning of spade card antenna using mean average loss of backpropagation neural network," Int. J. Adv. Comput. Sci. Appl., 2020.

[33] N. Chahat, J. Sauder, M. Mitchell, N. Beidleman, and G. Freebury, "One-Meter Deployable Mesh Reflector for Deep-Space Network Telecommunication at X-Band and Ka-Band," IEEE Trans. Antennas Propag., 2020, doi: 10.1109/TAP.2019.2943394.

[34] T. Reynalda, A. Munir, and E. Bharata, "Characterization of 4??4 high gain microstrip array antenna for $3.3 \mathrm{GHz}$ WiMAX application," in Proceedings of 2011 6th International Conference on Telecommunication Systems, Services, and Applications, TSSA 2011, 2011, doi: 10.1109/TSSA.2011.6095437.

$141 \mid \mathrm{P}$ a g e 
JEEMECS (Journal of Electrical Engineering, Mechatronic and Computer Science) ISSN 2614-4859

Vol. 3, No. 2, August 2020, pp. 135-142

\section{This page intentionally left blank}

142 | P a g e 